\title{
Conceptual framework for sustainable development of rural areas: environmental issues
}

\author{
Svetlana Sheina ${ }^{1}$, and Albina Fedorovskaya ${ }^{1, *}$, \\ ${ }^{1}$ Don State Technical University, Gagarin square 1, Rostov-on-Don, 344000, Russia
}

\begin{abstract}
This article dwells on elaboration of a conceptual framework for sustainable development of rural areas. It covers environmental issues of every stage of framework implementation in detail. Environmental assessment of the territory of Rostov Region has been carried out. Main parameters of the conceptual framework are given as conclusions to this article.
\end{abstract}

\section{Introduction}

Today, urban development policy is aimed at purposeful solution of topical issues of spatial development and issues at long-term prospect on the basis of the state-determined goals and scientific knowledge of development regularities of specific territories. The issue of development and planning of rural territories during urbanization and under the lack of uniformity in the development of the Russian Federation subjects (down to degradation of separate urbanized regions) is being extremely crucial.

Rural areas possess a prominent demographic, historical and cultural, natural and economical potential which without any doubt allows to provide for complete employment and high level and quality of living for the rural area population, as well as for sustainable development under the rational and efficient utilization thereof. Territories of this kind can be viewed as a form of spatial relations between landscape, economics, and population [1,2].

A comprehensive approach allows to achieve a complex solution of territorial and spatial development problems in rural settlements there where they are one of the most important elements of the territorial structure, taking simultaneously into account the conditions, economic activity, historical and cultural and social and economic development of the region and the state as a whole [1-3].

Solution of problems in the sphere of sustainable development of a territory is impossible without a comprehensive assessment of such problems; the results of such assessment reflect the social and economic state of the territory and help to develop effective economic and arrangement-related measures aimed at enhancement of sustainability and integrity of the territorial system, taking into account the raw materials potential, the state of environment, and the historical and cultural peculiarities of the territory.

State regulation of sustainable development of the rural areas promotes a development of measures to formalize a legal aspect of fulfillment of social, economic, and environmental elements of the issue under consideration [6-9].

\footnotetext{
*Corresponding author: bina-87@mail.ru
} 
Currently, the strategic goal of the state national policy is to create favorable conditions for life activities, and increase of life quality for population. Fulfillment of these conditions will create prerequisites for sustainable development of the territory pursuant to the Federal Target Program "Sustainable Development of Rural Territories for the years 2014 - 2017, and for the period till 2020", adopted under the Russian Federation Government Resolution No. 598 dd. July 15, 2013.

Rostov Region is one of the largest agricultural regions of the Russian Federation. 12\% of the GRP of Rostov Region is generated in the agricultural sector. Farmlands occupy 8.2 million hectares, and arable land - 5.8 million hectares. In terms of the area of agricultural land and the area of grain crops, the region ranks second in the Russian Federation. Soil and climatic conditions of the region are favorable for production of many types of agricultural products. There are 4.2 million people living in the region of which one third, that is 1.4 million people, resides in the countryside.

Six main natural and agricultural zones are distinguished in Rostov Region, in which 358 rural settlements are located (see Table 2).

Table 1. Natural and agricultural zones of Rostov Region.

\begin{tabular}{|c|c|c|}
\hline $\begin{array}{l}\text { Agricultural } \\
\text { zone }\end{array}$ & Districts & Direction of production \\
\hline $\begin{array}{l}\text { North- } \\
\text { Western } \\
\text { zone }\end{array}$ & $\begin{array}{l}\text { Bokovskiy, Verkhnedonskoy, } \\
\text { Kamenskiy, Kasharskiy, Krasnosulinskiy, } \\
\text { Millerovskiy, Tarasovskiy, Chertkovskiy, } \\
\text { Sholokhovskiy }\end{array}$ & $\begin{array}{l}\text { Cattle breeding (pig breeding), } \\
\text { grain production }\end{array}$ \\
\hline $\begin{array}{l}\text { North- } \\
\text { Eastern zone }\end{array}$ & $\begin{array}{l}\text { Belokalitvenskiy, Konstantinovskiy, } \\
\text { Milutinskiy, Morozovskiy, Oblivskiy, } \\
\text { Sovietskiy, Tatsinskiy, Ust-Donetskiy, } \\
\text { Tsimlyanskiy }\end{array}$ & $\begin{array}{l}\text { Cattle breeding: ping breeding } \\
\text { and poultry breeding, grain } \\
\text { production }\end{array}$ \\
\hline $\begin{array}{l}\text { Central } \\
\text { irrigated } \\
\text { zone }\end{array}$ & $\begin{array}{lr}\text { Bagayevskiy, } & \text { Veselovskiy, } \\
\text { Volgodonskiy, } & \text { Martynovskiy, } \\
\text { Proletarskiy, Semikarakorskiy }\end{array}$ & $\begin{array}{l}\text { Cattle breeding, vegetable } \\
\text { farming: wine-growing and rice } \\
\text { growing }\end{array}$ \\
\hline $\begin{array}{l}\text { Priazovskaya } \\
\text { zone }\end{array}$ & $\begin{array}{lr}\text { Azovskiy, Aksayskiy, } & \text { Kuibyshevskiy, } \\
\text { Kurganinskiy, } & \text { Matveyevo- } \\
\text { Myasnikovskiy, } & \text { Neklinovskiy, } \\
\text { Oktyabrskiy, Rodionovo-Nesvetayskiy }\end{array}$ & $\begin{array}{l}\text { Cattle breeding, grain } \\
\text { productions; suburban farms are } \\
\text { wide spread }\end{array}$ \\
\hline $\begin{array}{l}\text { Southern } \\
\text { zone }\end{array}$ & $\begin{array}{l}\text { Yegorlykskiy, Zernogradskiy, } \\
\text { Kagalnitskiy, Peschanokopskiy, Salskiy, } \\
\text { Tselinskiy }\end{array}$ & $\begin{array}{l}\text { Cattle breeding (pig breeding), } \\
\text { grain production }\end{array}$ \\
\hline Eastern & $\begin{array}{l}\text { Dubovskiy, } \\
\text { Zimovnikovskiy, } \\
\text { Remontnenskiy }\end{array}$ & $\begin{array}{l}\text { Grain production, } \\
\text { breeding (pig breeding) }\end{array}$ \\
\hline
\end{tabular}

Sustainable development of an area can be represented as a $\mathrm{n}$ interaction between three components: economic, social, and environmental.

\section{Experimental}

Environmental component of sustainable development shall provide for preservation of selfrecovery ability of ecological systems under consideration of natural resources and environmental pollution level. Electronic maps for spatial analysis of natural resources of Rostov Region based on such criteria as soils, agroclimatic conditions, fruitfulness of arable lands (see fig. 1(a. b) and 2a) have been prepared using ArcGIS platform. Environmental status of Rostov Region is shown on Fig. $2 b$. 
a)

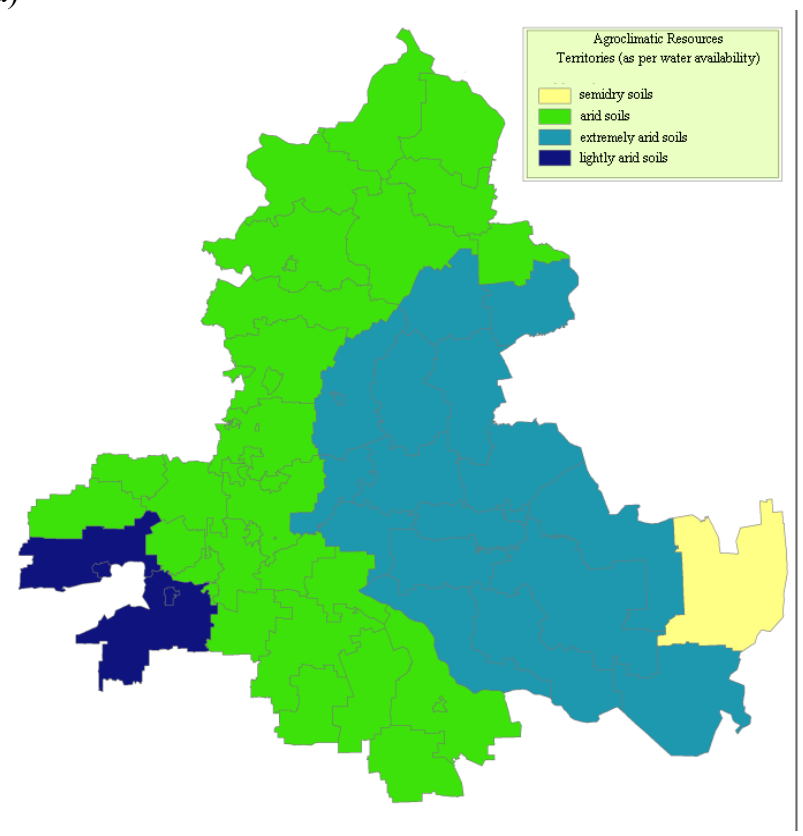

b)

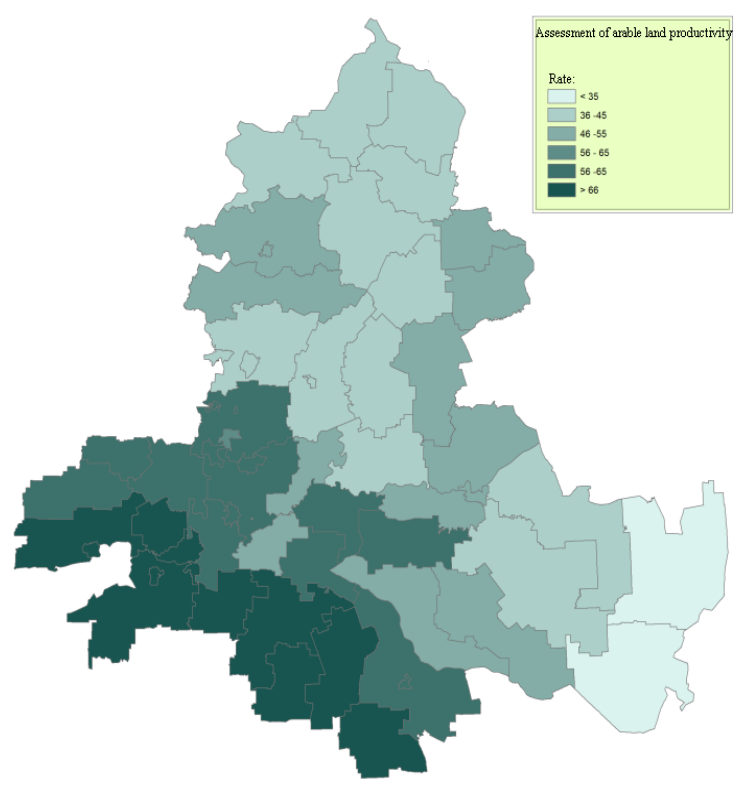

Fig. 1. a) Agroclimatic resources b) assessment of arable lands productivity. 
a)

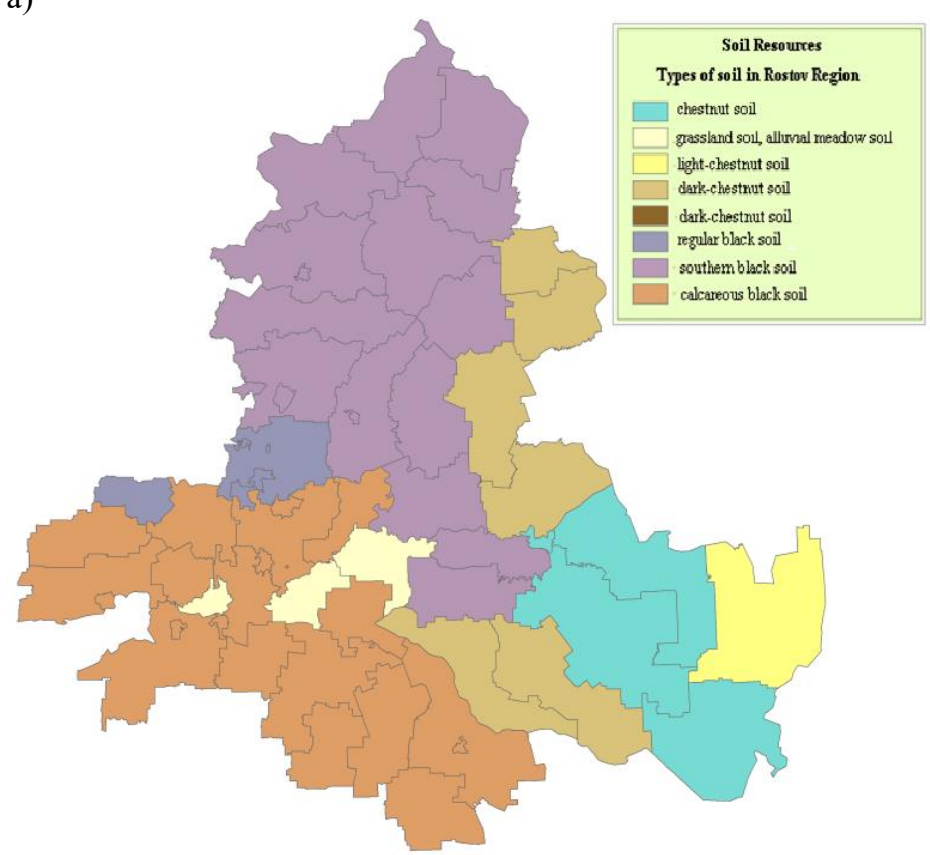

b)

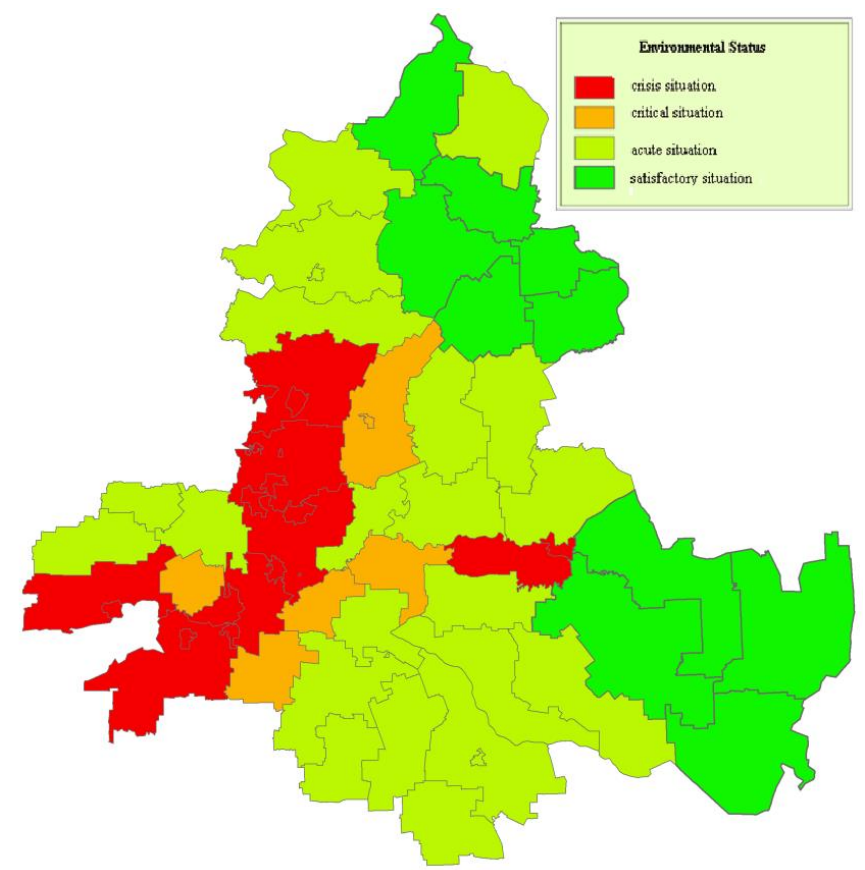

Fig. 2. a) soil resources, b) environmental status.

Efficient utilization and sustainable development of rural territories depend on the system of essential factors i. e. sustainability criteria. Under sustainability criteria the qualitative and quantitative values of social and economical and natural and ecological potentials of the territorial systems. 
This group of criteria includes, in particular, a quality assessment of the environment. There are numerous environmental problems in Rostov Region that create significant obstacles to the territorial development in many areas. Serious manifestations of these unfavorable factors may cast doubt on the prospect of even a minor realization of the growth potential.

Under modern conditions, the danger to the ecological status of agricultural lands lies in the decrease of the general level of farming culture and the failure to comply with compulsory soil protection and other environmental measures. The agricultural load in the areas of the region (in points) is shown in Figure 3a. Five most characteristic indicators were taken as a basis in order to determine the agricultural load on the environment: the share of arable land in the structure of agricultural lands, the share of irrigated lands, fixed assets per 100 hectares of agricultural land, the amount of fertilizers applied per hectare of agricultural land and the density of large cattle on 100 hectares of agricultural land.

Ever-increasing anthropogenic impact and excursive exploitation of natural resources reinforce the degradation of agricultural lands. In most major agricultural regions of Russia, the plough disturbance of area exceeds the environmentally allowable limits and entails deterioration of hydrological regime in catch basins, decreases the self-regulation of natural complexes and productivity sustenance of agricultural lands. As a result of intensive anthropogenic impact, all lands in the region are affected by such degradation processes as wind and water erosion, excessive moistening, mechanical disturbance, and several others. The entire amount of anthropogenic factors can be united into four groups.

\section{Results}

An aggregate of natural resources of the region on the first stage, and anthropogenic impact assessment on the second stage is the perquisite for comprehensive analysis of the area. For this purpose, the groups of anthropogenic environmental impact factors must be distinguished, and then, this aggregate must be summed into an integrated index of anthropogenic impact.

Table 2. Groups of anthropogenic environmental impact factors.

\begin{tabular}{|c|c|c|}
\hline No. & Group & Factor \\
\hline \multirow[t]{6}{*}{1.} & \multirow[t]{6}{*}{ Bodies } & soils \\
\hline & & terrain \\
\hline & & water bodies \\
\hline & & edifices \\
\hline & & plants \\
\hline & & animals \\
\hline \multirow[t]{3}{*}{2.} & \multirow[t]{3}{*}{ Matters } & chemical elements \\
\hline & & radioactive materials \\
\hline & & - $\quad$ exhaust from enterprises \\
\hline \multirow[t]{3}{*}{3.} & \multirow[t]{3}{*}{ Processes } & Soil tillage \\
\hline & & Corrosion of metals \\
\hline & & Motion of animals and plants \\
\hline \multirow[t]{5}{*}{4.} & \multirow[t]{5}{*}{ Factors-phenomena } & Air pollution \\
\hline & & Water pollution \\
\hline & & Soil pollution \\
\hline & & Radio waves \\
\hline & & Electrical current, etc. \\
\hline
\end{tabular}


a)

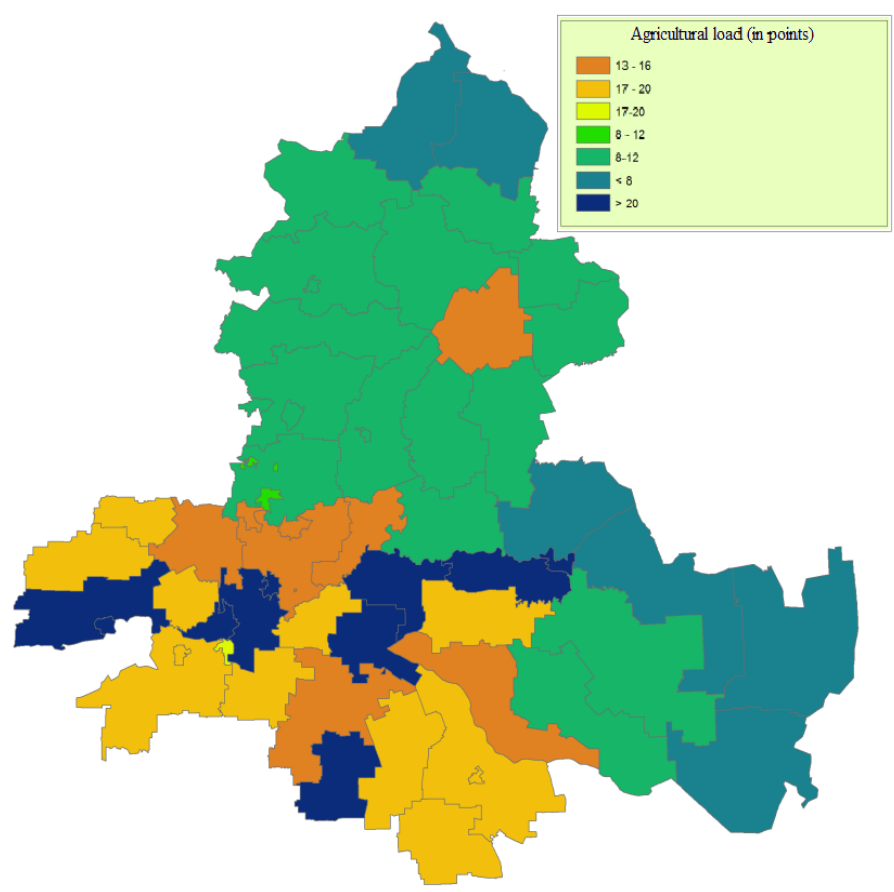

b)

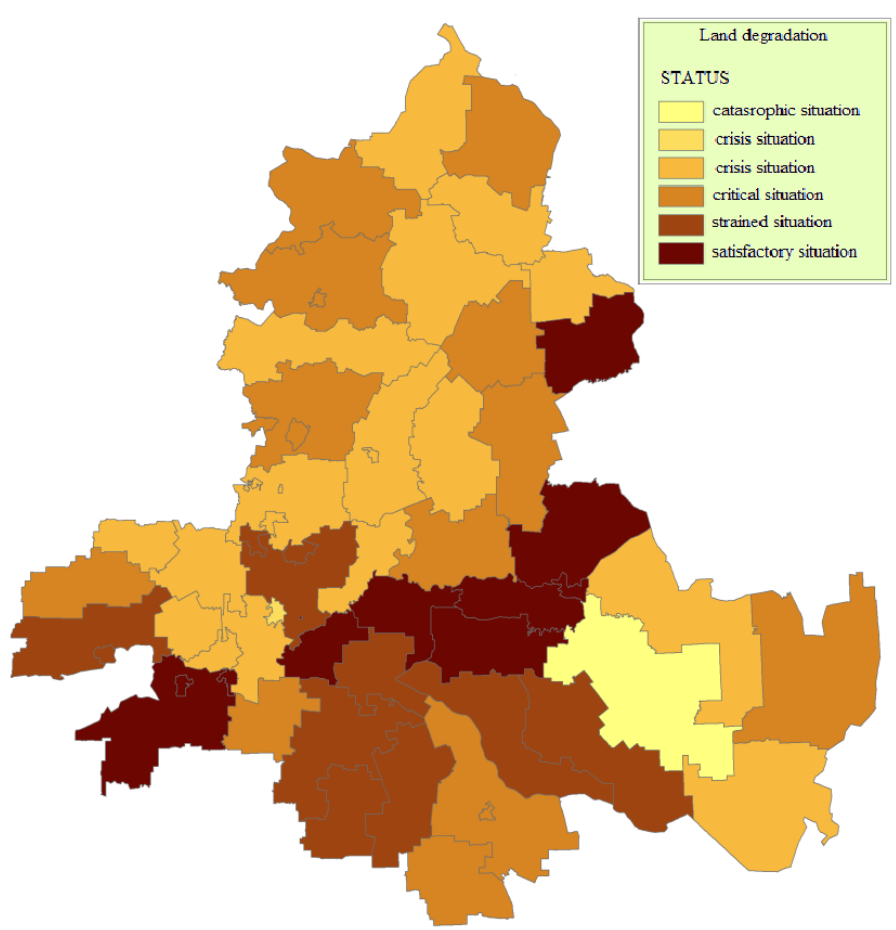

Fig. 3. a) Agricultural load map; b) Land degradation map. 
Integral estimation as per anthropogenic impact was made by summing the degrees of demographic, industrial, agricultural and transport impacts on the natural environment. The analysis revealed that the situation with anthropogenic impact in the region has become critical. It must nevertheless be mentioned that the spatial differences are quite significant. The integrated index of anthropogenic impact is shown on the map (see Fig. 4 ).

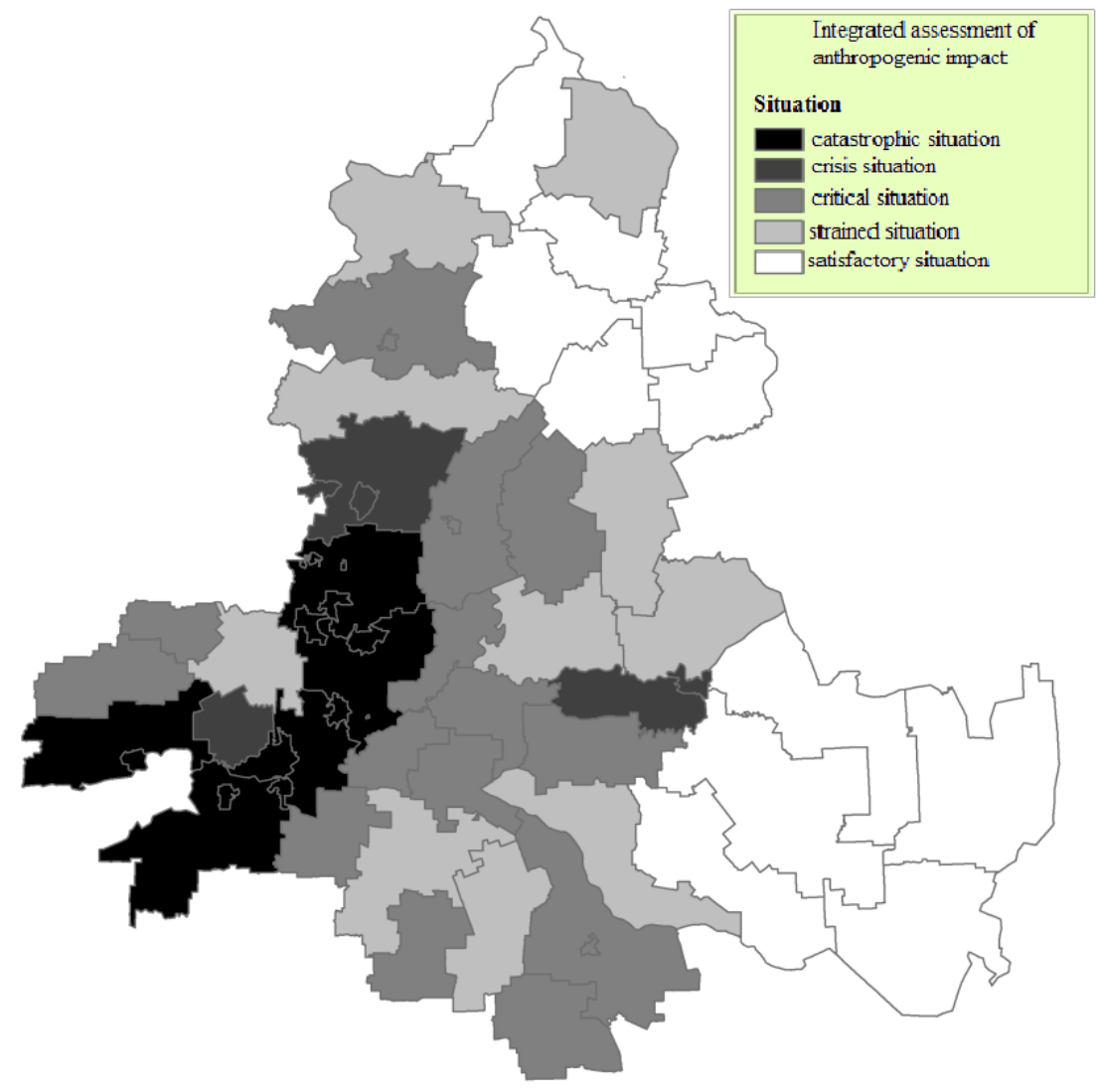

Fig. 4. Integrated index of anthropogenic impact.

Integrated index of anthropogenic impact allows to distinguish the areas in which the development of a specific line of agricultural activity is unadvisable, for instance: EasternDonbass and Rostov agglomerations. At the same time, this index allows to pay attention to the territories where the development of the agro-industrial complex is quite possible. Such possibility is determined by means of selection of scalable environmental protective measures and economic factors which further promote the agricultural activities.

Sustainable development of any rural area is determined by an aggregate of the factors mentioned above. Disregard to any of these entails a misbalance and dysfunction of sustainable development process. The basis for management of the factors is the system analysis methodology with which it is possible to reveal these factors and the relations between them. Elaboration of strategy for solution of sustainable development problems for specific rural area is only possible after application of the mentioned methodology.

Production expansion of the agricultural enterprises, self-management of business entities, diversification of agricultural economy, technical modernization of its branches within the agro-industrial complex, investment generation - these are the main directions to work in in order to enhance the sustainability of the rural areas development which in its turn 
will facilitate optimal utilization of resources, stable development of agricultural economics, profitability of agricultural products manufacturers, improvement of quality and level of living for the rural population, etc.

\section{Conclusions}

Sustainable development of rural areas will promote a quick growth of agricultural economy, enhance the local employment, level and quality of living for the population, and preserve the environment. For this purpose, a conceptual framework for sustainable development of rural areas has been developed; this framework is an interconnected system which comprises the tasks, the goals and the factors that influence the sustainability of the territories, the mechanisms that provide for development, and the instruments of sustainability in the whole, and in separate (see Table 2).

Table 3. Conceptual framework for sustainable development of rural areas.

\begin{tabular}{|c|c|c|}
\hline \multicolumn{3}{|c|}{ SUSTAINABLE DEVELOPMENT OF RURAL AREAS } \\
\hline \multicolumn{3}{|c|}{$\begin{array}{l}\text { Goals: arrangement of conditions for population well-being, formation of well-developed } \\
\text { territorial system, enhancement of agriculture efficiency, assurance of rational natural resources } \\
\text { utilization }\end{array}$} \\
\hline $\begin{array}{l}\text { SOCIAL ASPECT } \\
\text { Raising the level and } \\
\text { quality of life for the } \\
\text { population, preservation } \\
\text { and enhancement of the } \\
\text { cultural potential of rural } \\
\text { areas }\end{array}$ & $\begin{array}{l}\text { ECONOMIC ASPECT } \\
\text { Ensuring sustainable growth } \\
\text { of rural economy and } \\
\text { agricultural efficiency }\end{array}$ & $\begin{array}{l}\text { ECOLOGICAL ASPECT } \\
\text { Assurance of rational } \\
\text { utilization of natural resources } \\
\text { and preservation of natural } \\
\text { environment }\end{array}$ \\
\hline \multicolumn{3}{|c|}{$\begin{array}{l}\text { Tasks: establishment of economic basis for rural development sufficient to maintain social and } \\
\text { natural potential }\end{array}$} \\
\hline $\begin{array}{l}\text { SOCIAL ASPECT } \\
\text { Increase of employment } \\
\text { and incomes of the } \\
\text { population, stimulation of } \\
\text { demographic growth, } \\
\text { widened accessibility of } \\
\text { social services, } \\
\text { improvement of living } \\
\text { conditions for the } \\
\text { population }\end{array}$ & $\begin{array}{l}\text { ECONOMIC ASPECT } \\
\text { Arrangement of conditions for } \\
\text { increase of the rural } \\
\text { production efficiency, } \\
\text { expansion of generation } \\
\text { income sources for the } \\
\text { population. }\end{array}$ & $\begin{array}{l}\text { ECOLOGICAL ASPECT } \\
\text { Assurance of natural } \\
\text { development of ecosystems, } \\
\text { preservation and restoration of } \\
\text { unique natural complexes in } \\
\text { the course of solution of } \\
\text { problems in the specific area }\end{array}$ \\
\hline \multicolumn{3}{|c|}{ Factors: availability of infrastructure, investment prospects in the area } \\
\hline $\begin{array}{l}\text { SOCIAL ASPECT } \\
\text { Social infrastructure, labor } \\
\text { resources, demographic } \\
\text { situation }\end{array}$ & $\begin{array}{l}\text { ECONOMIC ASPECT } \\
\text { Competition, diversity of } \\
\text { activities, transport and utility } \\
\text { infrastructures }\end{array}$ & $\begin{array}{l}\text { ECOLOGICAL ASPECT } \\
\text { Availability of } \\
\text { environmentally safe } \\
\text { measures, environmental } \\
\text { status assessment }\end{array}$ \\
\hline \multicolumn{3}{|c|}{$\begin{array}{l}\text { Mechanisms: methods, forms, and ways to provide for interaction between the social, } \\
\text { economic and ecological components of the rural areas }\end{array}$} \\
\hline $\begin{array}{l}\text { SOCIAL ASPECT } \\
\text { Extension of social } \\
\text { partnership between the } \\
\text { state and the population }\end{array}$ & $\begin{array}{l}\text { ECONOMIC ASPECT } \\
\text { Extension of production, } \\
\text { innovations and investments }\end{array}$ & $\begin{array}{l}\text { ECOLOGICAL ASPECT } \\
\text { Availability of } \\
\text { environmentally safe } \\
\text { measures, environmental } \\
\text { status assessment }\end{array}$ \\
\hline
\end{tabular}


Implementation of the above mechanisms will thus have a positive socio-economic and environmental effect on the development of rural areas. However, implementation of these mechanisms is a complex, time-consuming and costly process while presently many rural areas are experiencing a crisis that manifests itself in the deterioration of the demographic situation, low level and poor quality of life of rural population and high level of unemployment, irrational use of natural resources, etc. The research conducted showed that monitoring of the sustainable development of the area will help assess the level of sustainability and choose the right directions of development for certain rural settlements that can bring them to a new level of development.

\section{References}

1. S. Sheina, W. Dietmar, R. Matveyko, L. Teryukova, European science review 11-12, 214-219 (2015)

2. P. Grabovy, A. Naumov, I. Avilova, J. International Business Management 10, 13541364 (2016)

3. S. Sheina, V. Shumeev, R. Matveyko, L. Babenko, A. Khamavova, A. Kartamysheva, In Computing in Civil and Building Engineering: Proceedings of the International Conference. -Nottingham: Nottingham University Press, 129 -141 (2010)

4. L. Girya, S. Sheina, P Fedyaeva, Journal of Applied Engineering Research. 8, 19263$19276(2015)$

5. A. Sheina, A. Khamavova, J. Procedia Engineering 150, 1960-1965 (2016)

6. S. Sheina, L. Babenko, J. Advanced Materials Research 1044-1045, 1517 (2014)

7. N. Makisha, V. Scherbakov, A. Smirnov, E. Scherbina, International Journal of Applied Engineering Research 10(24), $44347-44349$ (2015)

8. D. Vlasov, N. Danilina, Advanced Materials Research 869-870, 201-204 (2014)

9. I.L. Kievskiy, L.V. Kievskiy, International Journal of Applied Engineering Research 10(20), 40893-40898 (2015) 